\title{
Condensation and mould in Australian homes
}

\author{
Mark Dewsbury ${ }^{\mathrm{a}}$, Shruti Nath ${ }^{\mathrm{a}}$, Toba Olaoye ${ }^{\mathrm{a}}$, Hartwig Kunzel ${ }^{\mathrm{b}}$ \\ a School of Architecture and Design, University of Tasmania, Launceston, Australia \\ b Fraunhofer Institute of Building Physics, Holzkirchen, Germany
}

\begin{abstract}
Since 2002, the Australian building regulations have required increasing levels of insulation and building sealing. The focus of these regulations has been to reduce energy consumption associated with the use of heating and cooling appliances, and by default, reduce Australia's greenhouse gas emissions. However, this singular focus has allowed building regulations to develop which have promoted the design and construction of new buildings that allow moisture to form and accumulate and support the growth of mould on interior and interstitial surfaces. Since 2010, the team at the University of Tasmania have been recommending regulatory change, with the first significant success in 2019. This paper will discuss the Australian experience, our research focuses and our hopes for the future.
\end{abstract}

Peer-review under the responsibility of the organizing committee of the ICMB21.

Keywords: Condensation; Mould; Hygrothermal; Bio-hygrothermal; Energy Efficiency; Timber Framed Construction.

\section{Introduction}

The primary function of the Australian building regulations is the provision of safe and healthy buildings[1]. As the national constitution does not include these sorts of matters, the development of building regulations falls within State Government control. Within this context, Australia's eight jurisdictions (six states and two territories), each developed their own building regulations and delegated development management responsibilities to Local Government agencies. Acknowledging this diversity, in 1965 the state governments and local government agencies agreed that a national approach was needed. It took from 1965 to 1990 for many Local governments and State governments to agree on a single national building regulation, which was known as the Building Code of Australia, which from 2011 became known as the National Construction Code [2]. As the regulations evolved, the goals were modified to include a minimum performance requirement for the safety, health, amenity, accessibility, and sustainability of certain buildings. The first stage of sustainability performance requirements were added in 2003 , to reduce greenhouse gas emissions, which may result from heating and cooling a home [3]. Since these first energy efficiency regulations were required, enhancements to the thermal performance of housing have occurred in 2004, 2007 and 2010, representing 4 Star, 5 Star and 6 Star respectively. The Star system represents a relative amount of energy to heat and/or cool a home. In essence a 0 Star home would be the same as the exterior environment, requiring the most amount of greenhouse gas emitting energy to make the house thermally comfortable. While a 10 Star house would need nil energy for heating or cooling purposes. Even though the national building regulation established the minimum requirements, each state chooses whether to adopt individual clauses. Even though it is 11 years since the 6 Star energy efficiency requirements were published, some states, or regions within states, have only adopted the 5 Star energy efficiency requirement.

Research at the University of Tasmania developed a strong collaboration with the Tasmania State Government, federal government agencies and a broad mix of manufacturers and design and construction professional associations. These collaborations led projects which were aimed at providing real world guidance to the design and construction industry, whilst providing empirical data to inform regulatory development. The projects included the "No-Bills' house, thermal performance test buildings [4], best 5 Star Houses and guidance regarding subfloor insulation, and the opportunities for using mass timber products as thermal mass. In 2007 UTAS researchers raised significant concern about the vapour impermeable materials commonly used in the external envelopes of most housing. This awareness and knowledge of experiences in other nations developed a strong liaison between state government building regulators and the university researchers.

In 2014, four years after the 6 Star regulations came into effect, many homeowners, and design and construction professionals started to report condensation and mould problems within homes. This included housing located in Tasmania, Victoria and New South Wales, Australian Capital Territory and Queensland, which includes warm temperate to cool temperate climates. This led to research activities which observed and simulated moisture and mould growth $[5,6]$ and a nationwide survey to establish the extent of the problem [7]. The slow response and development of the regulations reflects the guiding principles of the national building regulations and the current conservative political framework. The successive conservative governments have focused on a mantra of 'less regulation' with an expectation that 'industry' will address any issues. 


\section{ICMB21}

\section{Methodology}

To provide national guidance on matters related to condensation, moisture accumulation and mould growth, required a multifacetted approach that combined desktop simulation with empirical data and laboratory testing. Each of these is described briefly below. The desktop simulation-based research commenced with software which completed condensation risk analysis in a nontransient simplified method. This research was completed between 2014 and 2017 and used the British JPA software [8]. Recognising limitations with this type of method, the research adopted the use of the transient software WUFI, which included the development of climate files and other input interface softwares [9]. A focus on human health allowed the team to focus on bio-hygrothermal simulations [10]. The empirical data has included regular consultations with building/home-owners, design professionals (Architects, Building Designers and Engineers) and construction professionals. The laboratory testing has included the establishment of Australia's first hygrothermal material testing laboratory [11]. In the first stages of this new research program, the focus has been on measuring the water vapour resistivity properties of pliable membranes that are used as building wraps on Australian housing.

\section{Results}

The results are ongoing, especially within the context of empirical data. Alarmingly, many industry based enquiries are coming from homes that are more than six years old. These types of houses are not able to claim warranty, and, in most cases, the homeowners are unable to afford adequate remediation works. The transient bio-hygrothermal simulations results are providing guidance to state and national building regulatory development and the design and construction professions. The National Government's commitment to reduce greenhouse gas emissions, is keen to adopt the 7 Star metric in 2022, however, adequate consideration and condensation related regulatory development has not occurred. The material testing laboratory has been testing materials at different relative humidity's. That is, values that the material would experience within the external envelope of a building. Preliminary results have shown that the vapour resistivity properties do vary, subject to relative humidity.

\section{References}

1. $\mathrm{ABCB}$, The Building Code of Australia: 1996 Amendment 11, A.B.C. Board, Editor. 2002.

2. $\quad A B C B, N a t i o n a l$ construction code of Australia: volume 2, A.B.C. Board, Editor. 2011: Canberra.

3. ABCB, The Building Code of Australia: 1996 Amendment 12. 2003, Australian Building Codes Board.

4. Dewsbury, M., The empirical validation of house energy rating (HER) software for lightweight housing in cool temperate climates. 2015, New York: Springer Theses.

5. Dewsbury, M., et al., Condensation RIsk Mitigation for Tasmanian Housing (final report). 2018, University of Tasmania: School of Architecture and Design. p. 69.

6. Law, T. and M. Dewsbury, The Unintended Consequence of Building Sustainably in Australia, in Sustainable Development Research in the Asia-Pacific Region: Education, Cities, Infrastructure and Buildings, W.F.a.J.R.a.U. Iyer-Raniga, Editor. 2018, Springer International Publishing: Switzerland. p. 525-547.

7. Dewsbury, M., et al., Scoping study of condensation in residential buildings: final report. 2016, Australian Building Codes Board.

8. Dewsbury, M., T. Law, and A. Henderson, Investigation of destructive condensation in Australian cooltemperate buildings. 2016.

9. Nath, S. and M. Dewsbury. The use of an innovative hygrothermal simulation method to develop built fabric recommendations for southern Australia. in Revisiting the role of Architecture for 'Surviving' Development: 53rd International Conference of the Architectural Science Association 2019. 2019. IIT Roorkee, India: Architectural Science Association (ANZAScA).

10. Nath, S., et al., A bio-hygrothermal mould growth analysis of typical Australian residential wall systems, in The 54th International Conference of the Architectural Science Association (ANZASCA) 2020, A.G. Ali Ghaffarian oseini, and Nicola Naismith, Editor. 2020, Architectural Science Association: School of Future Environments, Built Environment Engineering, Auckland University of Technology, Auckland, NewZealand. p. 1-10.

11. Olaoye, T.S., M. Dewsbury, and H. Kunzel, A Method for Establishing a Hygrothermally Controlled Test Room for Measuring the Water Vapor Resistivity Characteristics of Construction Materials. Energies, 2021. 14(1): p. 21. 